\title{
Reflecting on hard and soft coups: a comparison of Aquarius by Kleber Mendonça Filho and Land in Anguish by Glauber Rocha
}

Carolin Overhoff Ferreira

\section{Introduction}

The impeachment process against Brazilian president Dilma Rousseff, voted in the Senate on 31 august 2016, has been considered a 'soft' or 'cold' coup, due to the supposed lack of legitimate legal grounds. Accused of "pedaladas fisciais," that is fiscal pedalling-1, Rousseff was considered guilty and removed from office. For many, especially the PT ("Partido de Trabalhadores" - the Brazilian worker's party) and other political allies, these are false allegations, since the moving of funds between government budgets by borrowing money from public banks is a common procedure, practiced by former presidents and still applied by governors in office. However, it does in fact cover gaps by giving a wrong impression of the country's actual financial situation. Even though it constitutes a crime under Brazilian law, this practice has never been prosecuted and is still widely used. Hence, opponents of the impeachment understand that there was a tangible bending and ideologically inspired interpretation of laws by the highest court, the parliament and the senate. In fact, many sustain that the so-called soft coup stems from the desire to get rid of a government that implemented more social welfare programs than ever before in Brazil's history and lifted 36 million people out of poverty. While necessary reforms - agrarian, fiscal and of the political system - were not undertaken by the PT government, in power since 2003, the very fact that the deeply unjust distribution of wealth in Brazil, which still reflects the heritage of its colonial system and centuries as a producer of commodities based on slavery, got under pressure.

Rousseff's government was under heavy public siege due, firstly, to the economic crisis that followed the corruption scandal Mensalão, the monthly payment that made politicians from oppositional parties vote for the government projects in 2005 and 2006 under President Luiz Ignácio Lula da Silva, who has been sentenced to prison because of

\footnotetext{
${ }^{1}$ The issue is extremely polemical and there are highly diverging positions. Various international newspapers have tried to give an account of the problem. See for example Joe Leahy, "What is Brazil's president Dilma Rousseff accused of?" www.ft.com, 12 May 2016. Web. 26 Sept. 2016.
} 
corruption. For similar reasons, a second source of negative press was the Petrolão, the deviation of money from the state oil company, revealed in 2014. Despite these cases, the impeachment process is internationally understood as a vote of no confidence, which is in fact inexistent in Brazil's constitution. It also needs to be remembered that the political and economic crises resulting from the investigation of the corruption schemes affects politicians from all parties and all three institutions of power. Approximately $60 \%$ of the Parliament and Senate members are being or will be prosecuted, some of them already resigned or were sentenced to prison. There is of course worry that the so-called soft coup might lead to political deals.

This complex crisis has left nobody indifferent in Brazil, including the arts. In fact, when the film Aquarius by Kleber Mendonça Filho premiered at the International Film Festivel in Cannes 2016, director and cast used the international platform to protest publically. When it opened in Brazil it was applauded after screenings and the anger about the loss of democracy was expressed through cries of "Fora Temer," "Out with Temer" (the new president, former vice-president of Rousseff). There were consequences' ${ }^{2}$ First the film was rated 18, which, after protest, was lowered to 16 . Then it was excluded from representing the Oscars, a choice interpreted as another retaliation against the political positioning at Cannes ${ }^{3}$.

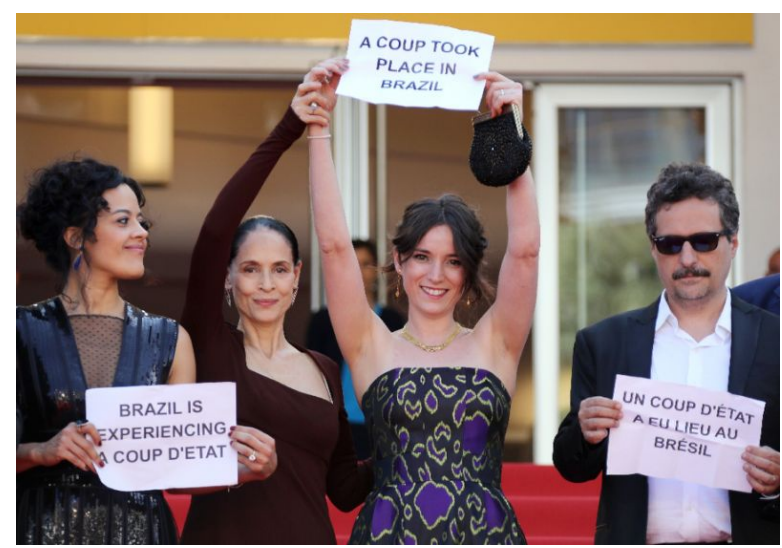

Figure 1: Cast and director protesting at the Cannes Film Festival in 2016 (C AFP Photo/Valery Hache)

\footnotetext{
${ }^{2}$ The protests and its consequences, as well as the polemics and marketing strategy are well described in El Pais Brasil by Camila Moraes.

${ }^{3}$ Two polemical occurrences that even The New York Times covered in an article by Simon Romero.
}

$\mathrm{S}^{\text {RASILIANA-Journal for Brazilian Studies. Vol. 6, n.1 (December, 2017). ISSN 2245-4373. }}$ 
Albeit this short introduction on the question of the soft coup, my interest here is, obviously, not to take sides but to contextualize briefly my analysis of Aquarius. However, according to the political statement at Cannes and the subsequent biased critique of the Brazilian press, I will read the film, in line with the French philosopher Jacques Rancière (2011), who understands the aesthetic as political. What is more, I will compare Aquarius, produced before but launched after the soft coup, with a now canonical film on a hard coup, Glauber Rocha's Land in Anguish, classically interpreted as an allegory of the 1964 military putsch and as a deep insight into Brazil's and Latin-America's political mechanisms of authoritarianism and populism. In fact, I will ask if any of the two films can be read as a diagnosis of Brazil, and if so how. To do so my analysis is based on German philosopher Martin Seel's (2013) anthropological definition of film that understands the audiovisual media as the art form that most strongly is capable of moving us. Being moved while watching a film, which always is a cutout of our world, Seel (2013) suggests, might imply that we ourselves might move, intellectually. Even though he does not say so, I would like to link this proposition to Rancière (2011) and understand the idea of being moved also as a potential of taking action as well as a redistribuition of the sensible by means of this cutout. Let me now make a comparative discussion of Aquarius' and Land in Anguish's capacity to move us and to make us move, and ask if the films can make us feel and understand Brazil so as to make us act, eventually, within its socio-political structure in case they present a dissent with the current distribution of the sensible, i.e. our world.

\section{Being moved, move and act}

Let me briefly sketch my theoretical framework. Martin Seel's anthropological definition of film focuses the spectator's position towards the media, as well as his or her reception, which he contrasts with other art forms, namely architecture, music, drama a literary narrative. However, as any art form, Seel (2013) says, film offers us the possibility to face as much ourselves as the world. Thus, it gives us a chance to ask ourselves how we want to be defined (Seel 2013, p. 15) since film plays with the possibilities and impossibilities of human experiences and expectations by simulating them in divers constellations. But, differently from other art forms, film constructs a tension between the phenomenological movement (our perception) and being moved in psycho-physical terms (our reaction to our perception) (Seel, 2013, p. 234). This is due to our involvement with film's complex relations of time and space, image and sound, narration and reflection, motion and emotion, appearance and

$\mathrm{B}^{\text {RASILIANA- Journal for Brazilian Studies. Vol. 6, n.1 (December, 2017). ISSN 2245-4373. }}$ 
disappearance, presence and absence. While we are watching variations of our inner life and outer reality (Seel, 2013, p. 164), we are transported into an imaginary world created by these composite relations. However, given film's complexity, its sensual and cognitive affection, no other art form is as radical in making the spectator part of its imagination (Seel, 2013, p. 61). The created fictional world is, indeed, a cosmos of its own. Yet, it is precisely the exploration of this imagined world that makes it possible for us to relate it to our real and inner worlds (Seel, 2013, p. 145).

Paradoxically, by limiting the perception of our world into an imaginary one based on framing, montage and edited sound, film enhances it, offering complex and unstable perspectives and feelings towards its characters, which should not be mistaken with identification (Seel, 2013, p. 215, p. 218). However, film's narratives can point out possible changes, since they represent at the same time the individuality of biographical as well as of historical processes (Seel, 2013, p. 124). And they invite us to comment, justify or evaluate them (Seel, 2013, p. 125), which will depend on our lives' experiences. Films do not only instigate us to react with our senses but also to interpret them with our minds (Seel, 2013, p. 238), stimulating as such a reception that moves us and might make us move by engaging with our physical and psychic memory (Seel, 2013, p. 203). Seel concludes that even though film is the art form that allows us to enjoy and even celebrate our passivity like no otherhe calls this "let it happen" the ethos of film -, it can show us how we stand towards ourselves (Seel, 2013, p. 242).

The dialectic between the world we live in and the world constructed in film - which is always a construction and should not be theorized neither as realism or as illusionism leads to a dialectic reception that connects the sensible and the intelligible. However, Seel's (2013) anthropological approach does not see film necessarily as a potential for action. While I am not interested in perpetuating the idea of political art in the tradition of German playwright Bertolt Brecht, Rancière's idea of an emancipated spectator that is always active and passive, emotionally and intellectually involved might help to develop the understanding of the political potential of the films under discussion.

Rancière $(2006,2009)$ suggests a wider definition of politics by thinking it in terms of how the world is constituted and how activities and social roles are distributed in different times and spaces. As mentioned before, politics is a cutout of the world, exactly as film or any other art form. Art and politics are no longer different but follow the same rules, since both create a spatiotemporal sensorium, which might be in tune or not with the status quo, that is, the distribution of the sensible. Given the dialectic that film offers due to its cutout

$\mathrm{B}^{\text {RASILIANA- Journal for Brazilian Studies. Vol. 6, n.1 (December, 2017). ISSN 2245-4373. }}$ 
of reality, it might suggest dissent that aims for a redistribution. And since the spectator is passive and active while watching, this dissent can make him or her not only think but also lead to action. The analysis of a film's potential of dissent in terms of the distribution of the sensible makes it possible to speculate on its interest and capacity to make a spectator move, to use again Seel's expression, no only emotionally and intellectually but also to participate actively in reorganizing the construction of our world.

\section{Aquarius}

Which cut-out of our world do we encounter in Aquarius and does it offer dissent and a redistribution of the sensible? The film's protagonist Clara lives in a striving neighbourhood on the beach in Recife, the capital of Pernambuco. The state was Brazil's first economic nucleus and point of departure for the exportation of the Pau Brazil tree, which gave the country its name. Subsequently it became the biggest sugar producer in the world. As Kleber Mendonça Filho already suggested in his first feature film, $\mathrm{O}$ Som ao Redor/Neighbouring Sounds, from 2012, the old patriarchal family structures of colonialism, known as coronelismo, which characterized the sugar plantations and the government of the provinces, are still present in contemporary Brazilian society, as famous Brazilian anthropologists and sociologists pointed out at the beginning and throughout the twentieth century.

In his renowned Casa-grande e Senzala/The Masters and the Slaves, first published in 1933, Gilberto Freyre (1946) describes coronelismo as the key mechanism of order and obedience to shape a society based on patriarchal latifundist monocultures. Criticized for being an aristocratic theorizer, a conservative and almost nostalgic apologetic of a false racial democracy, by advocating that Brazil's vast miscegenation had "melded races and cultures like no other place on earth," (Celarent, 2010, p. 335) the author was straightforward in the analysis of its sadism and racism, which marked and prolonged the slave society, as well as in the description of the brutal reality of slavery.

In O povo brasileiro/The Brazilian People, Darcy Ribeiro (2000) also puts forward the idea of a homogenous culture, for which he was accused of being old-fashioned and even stereotypical, ignoring Brazil's ethnic and linguistic complexity (Balee, 2003, p. 236). However, the author was undoubtedly aware that Brazilian society maintained a deep divide between the ruling class and the people, made possible by the recognition of the

$\mathrm{B}^{\text {RASILIANA-Journal for Brazilian Studies. Vol. 6, n.1 (December, 2017). ISSN 2245-4373. }}$ 
social order as a holy system by the lower classes. In fact, Ribeiro (2000) describes the historically persistent lack of class struggle with the complete isolation of those who rule from those who are being ruled: "What is most serious is that this abyss does not lead to conflicts that tend to transpose it, because they crystallize in a modus vivendi that aparts the rich from the poor, as if they were castes and ghettos."

Both feature films by Kleber Mendonça propose that the division noted by Freyre and Ribeiro survived intact and that the traditional families, heirs of the latifundists, participate nowadays in the real estate business and its speculations, thus contributing to the gentrification of the capital by creating luxurious ghettos. Since Clara, who is the last inhabitant of a middle-class two-storey building, resists their financial offers, she gets bullied by the construction firm, but also by former owners and even her children. The coercion she suffers and the resistance she develops, indeed, the main conflict and the political centre of the film. As the screenshot bellow illustrates, it is the result of a new tension between the modus vivendi of the middle and the upper class, or, in other words of a new distribution of the sensible.

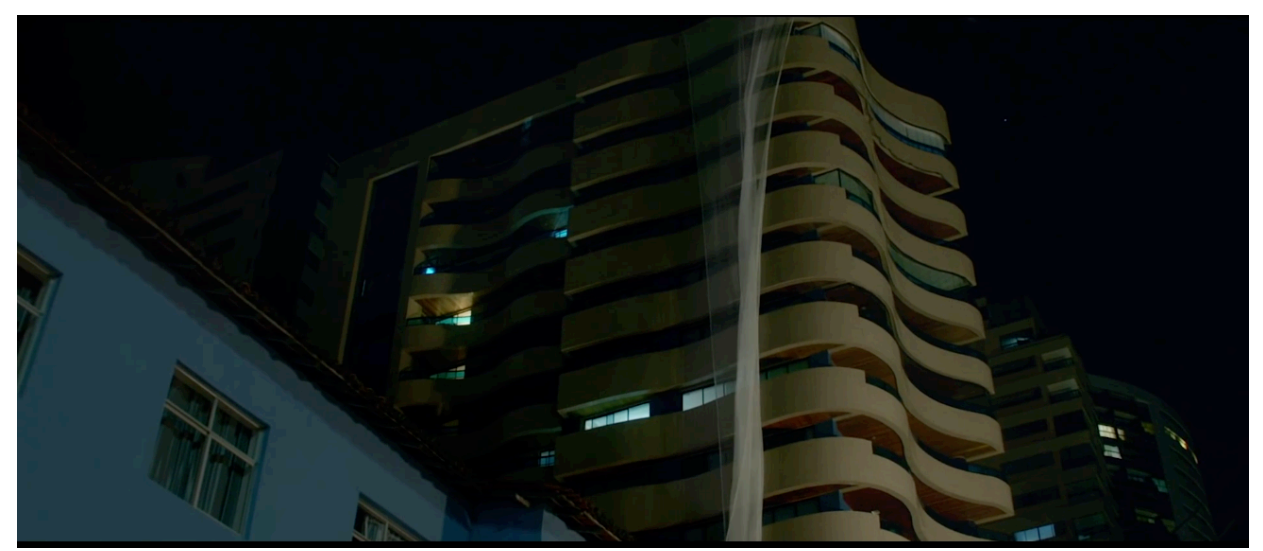

Figure 2: Clara's two-storey building and a luxurious apartment block in Aquarius (@ Vitrine Produções)

In the course of this 145-minute feature the growing intimidation suffered by Clara and its social embedding are developed at a slow-pace. Step by step we accompany Clara's (Sonia Braga) daily routine with scenes that expand on her personality, as well as her family and friend relationships. While the dramatic tension is low-key, intensifying slowly according to the increasing pressure on here, the inter-titles "Clara's hair", "Clara's love" and "Clara's cancer" indicate a three-act structure. As it happens, the conflict is introduced, steadily sharpened and finally resolved. The titles might seem at first of little significance but also participate in challenging the spectator to be more aware of the film's three key issues: one,

$\beta^{\text {RASILIANA- Journal for Brazilian Studies. Vol. 6, n.1 (December, 2017). ISSN 2245-4373. }}$ 
the protagonist's hair as a signifier of her survival from a cancer treatment; two, her relationships including sexual desires; and three, her outraged reaction to the coercion. With regard to the last, the cancer is clearly the film's central metaphor for the uncontrolled growth of the upper-class buildings that destroy more healthy ways of living since it participates in deepening the social divide. Thus, neoliberalism, the contemporary version of colonialism, is depicted as a cancer, which is destroying Recife's, Brazil's and, generally, a more human way of life.

The film starts by introducing Clara's capacity to fight and survive her breast cancer in the 1980s. It shows her as a loving niece, wife and mother hosting a birthday for her beloved aunt Lucia. Her passion for pop music - later we will learn she is a music critic characterizes her additionally as a free, modern and nonconformist spirit. Various scenes depict her treating everybody as equal since she takes great care in being respectful with maids and porters. The importance of family bonds, particularly with her brother and his wife, and free independent women like her girlfriends or the girlfriend of her nephew, is established in this prologue. The memory of this past, the openness and love it harbours, is presented throughout the film in shots of the apartment and its furniture or reminded through inserts of photographs. It is clearly the reason for Clara's deep connection with her home and her wish to remain living in it. In actual fact, the film constructs her as both modern-day and conservative -when it comes to values such as family and property without presenting this as contradictory.

After a flash forward, we see the now 65 year-old widowed Clara in her daily routine as a retired woman of the wealthy middle class. Scenes show her going to the beach in the mornings, reading, writing, giving interviews, visiting the grave of her husband, taking care of her toddler grandson, going out to dance with her friends, listening to music and often taking naps. Again, she is up-to-date but grounded. Aesthetically this routine develops by means of a slow-paced but rather classical narrative film style, creating sympathy for her and her calm life with close-up shots that linger on her still beautiful face.

Her time for leisure is guaranteed since the housework is taken care of by her maid Ladjane, whom Clara treats, as well as the lifeguard on the beach and other workers with friendliness. In the beginning the relationship between patron and servant is naturalized because conflict free. But Clara's comfortable and harmonious life starts getting tormented in two ways: first, by the construction firm that wants her out of the apartment, and second, by the embarrassment that the privileges based on social inequality produce when rich and poor unite in festive moments. Kleber Mendonça Filho develops an interesting dialectic

$\mathrm{S}^{\text {RASILIANA-Journal for Brazilian Studies. Vol. 6, n.1 (December, 2017). ISSN 2245-4373. }}$ 
between these two dimensions, being the conflict with the upper class subtle and the confrontations with the working class even more so.

The subtlety stems from the fact that the upper class, represented by the owners of the construction-company Bonfim - grandfather and grandson -, present their desire to get Clara out of the building at first in a cordial fashion. Confronted with her resistance the ambitious young Diego soon encounters perverse ways of harassing her. Sergio Buarque de Holanda (2012) famously questioned in his book Raizes da sociedade brasileira/Roots of Brazil the Brazilian cordiality as being antidemocratic and archaic because, "Our ordinary form of social co-existence is, in essence, the opposite of politeness. It can deceive in appearance (...) It is a disguise that permits each of us to preserve intact our sensibility and our emotions." (Holanda, 2012, p. 210) Interestingly, in the very beginning Clara asks her brother if any measure could be taken against the bullying, but since everything is being done amiably, he affirms that there is no legal way of stopping them. In other words, there is nothing that could defend Clara since the veil of affability protects the aggressors. It is this establishing of affectionate relationships that compromises the formation of a public order: "Indeed, wherever the idea of family prospers and has very solid bases - and mainly where the patriarchal kind of family predominates - the formation and the evolution of society along modern conceptions tend to be precarious and to fight against strong resistances", as Holanda (2012, p. 203-204) puts it.

In Aquarius, both lack of respect and the intention to impose personal interests upon others, which lies beneath the cordial mask, take shape in belligerent acts of growing intensity. Initially the company only puts patches on the neighbouring doors, then an orgy takes place in the upstairs apartment, followed by a populous meeting of an evangelical church, until, finally, a villainous act is discovered: the infestation of the building with termites that are devouring its structure. As a result, albeit its classical narrative, slow pace and focus on daily affairs, the film gains the quality of a psychological thriller. Many close ups and medium shots of Clara, who reacts according to her life experience with calm - she survived a cancer in her own body - testify her increasing discomfort, uneasiness and eventual horror.

But the growing discomfort does not paralyze Clara. On the contrary, it makes her act. Her actions are, nonetheless, shaped just like the subtle aggressions of the company by the boundaries of Brazilian cordiality. Initially, she tries to talk things over: with her children, morally lecturing Diego, and by asking a friend for help. This friend, owner of a newspaper and thus well connected, decides to reveal a story with which she can blackmail

$\mathrm{B}^{\text {RASILIANA- Journal for Brazilian Studies. Vol. 6, n.1 (December, 2017). ISSN 2245-4373. }}$ 
the real estate developer, even though he has family ties with the company. But the hardest blow - Clara's discovery that the termites have been mining the building's structure for months making it impossible for her to remain living there - makes her act more drastically. Not only does she take the incriminating documents, but also the termites to the construction firm. In an act of revolt, she returns the plague to those who put it on her. This act is illegal and not really effective but indicates a change in Brazil's social relations since Clara is no longer willing to be ordered around by the dominant class.

As mentioned earlier, Aquarius has a classic narrative structure, even though slower paced than conventional commercial cinema. What is more, its aesthetic strategy to engage its audience emotionally and cognitively in this new role for the middle class borrows from divers genres, especially the thriller given the plot of victimization, and works strongly with music as involving element. The dramatic suspense on which the narrative is based consists in making the spectator wonder how the intimidation will develop and if it will succeed. It achieves its climax when some of the other apartments are opened and the horror of the termite plague is revealed. The dramatic increase of pressure on Clara is presented in the already stated intimate close-ups and medium shots.

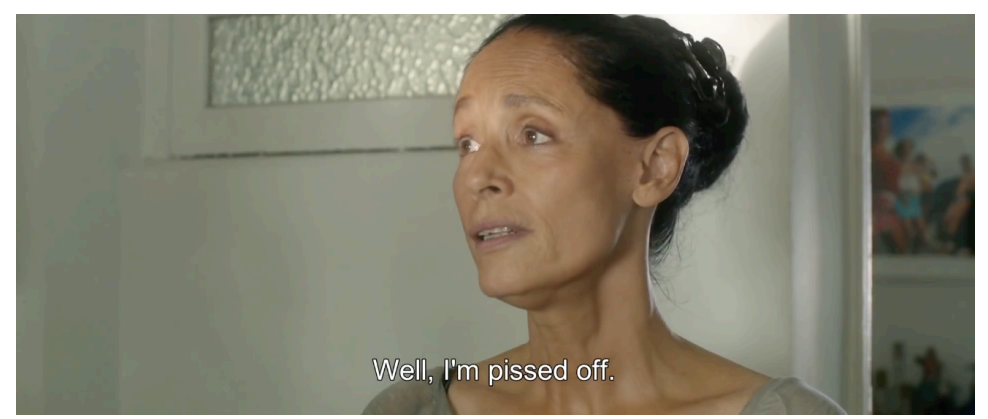

Figure 3: Close-up of Clara in Aquarius (@ Vitrine Produções)

The citation of thriller elements is not only related to the victimization of the character and the plot. There is also a series of visual thrills that are carefully planted and have an additional aim: to challenge the viewer's fear with regard to class division, which is still a result of the contemporary proto-slavery attitude of both upper and middle class towards domestic and other workers. The mise-en-scène of these sequences try to mislead the spectator with regard to social inequality that has resulted in the real world in extreme security measures, for example in the building of posh apartment buildings surrounded by

$\mathrm{B}^{\text {RASILIANA- Journal for Brazilian Studies. Vol. 6, n.1 (December, 2017). ISSN 2245-4373. }}$ 
fences and guards. It needs to be remembered that the fear of the social other is essential to a whole industry.

There are, indeed, three sequences that involve characters from the lower classes whose sudden appearance is filmed in a way that suggests imminent danger. In the beginning of the film a group of young dark-skinned adolescents appear at the beach where the middle class is engaged in yoga exercises. They are clearly depicted and sensed as intruders. As they reveal themselves as being harmless they are included into the group. Then there is sequence with a drug dealer who does business on the beach. After he is singled out and observed dealing, the spectator is confronted with a scene in which a former neighbour of Clara is much more aggressive than the skinny dealer. This other young man pressures her with threats to sell her apartment and accuses her of having an egotistic attitude. An over the shoulder shot shows them following Clara and creates suspense towards their intention. Surprisingly, they turn out to be friendly and well meaning by revealing the terrible secret of the termites to her.

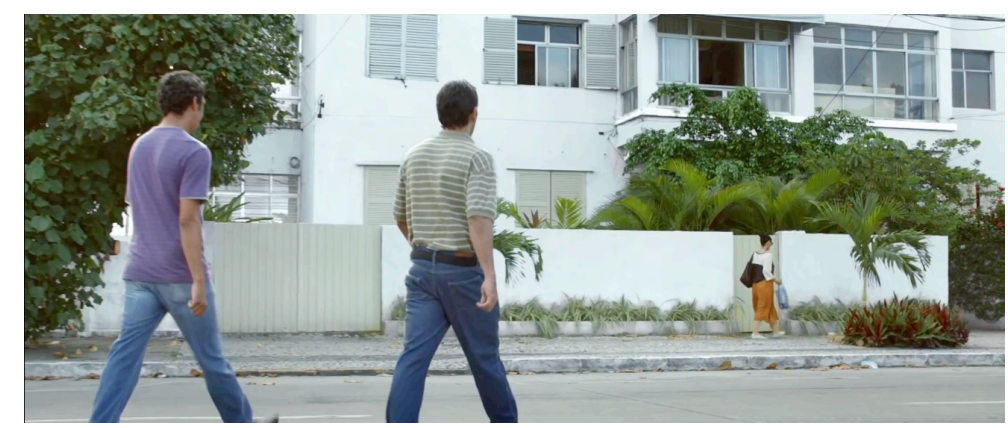

Figure 4: Workers following Clara in Aquarius (@ Vitrine Produções)

While these sequences play with the emotions of the middle class spectator by working on their fears, they also help to acknowledge that the upper class is much more vicious and dangerous for them. However, this conclusion implies an intellectual act after sensing anxiety - to make a move after having been moved to use Seel's terms - in order to become conscious of these anxieties, and an equally cognitive comparison of the attitudes of the different class representatives.

Apart from these visual thrills with regard to the feared victimization of the middle class, there are scenes that open up possibilities to question their self-righteousness regarding their privileged condition. They involve the victimization of the maid Ladjane by means of the story of her son, killed by a drunk driver who walked away without conviction

$\mathrm{B}^{\text {RASILIANA-Journal for Brazilian Studies. Vol. 6, n.1 (December, 2017). ISSN 2245-4373. }}$ 
- a common incident in the Brazilian legal system when it comes to felonies committed by the middle or upper class. The memory of her son, exposed with the help of photographic portrays, and the injustice she suffered, reinforced by repeating it three times - in a conversation between Clara and her nephew, during Ladjane's birthday party on her simple roof top, but also within Clara's home -, each time creating embarrassment for the members of the middle class.

The most ingenious but, when interpreted, the most revealing sequence regarding class difference and exploration is that of a former maid who is remembered during the same family reunion in which Ladjane shows her son's photograph. This other maid, who stole the family jewels, reappears briefly crossing the apartment in a short flash and then in a dream by Clara in which she observes her stealing while she is lying paralysed on her bed. The maid then tells her that she is bleeding, which in fact she is from the breast where she was operated. The spooky flash and dream scenes once again manifest the fear towards the lower classes, yet are actually inverted by Clara herself since they actually help her to realize what is going on. In fact, the dream is followed and thus causally linked to her reaction against the company, as though she had understood that, if she did not act against them, her illness could return. Due to their ambiguous feel and association with the unconscious, these episodes exceed from the spectator a greater cognitive effort than the aforementioned. Taken up this challenge, especially the dream reiterates that the true menace for middle class life - their distribution of the sensible - comes from the upper and not the lower classes. While the small fish steal jewels, the big fish take away an entire standard of living.

As stated earlier, music is another important element to engage the spectator emotionally. The feelings of the characters, especially Clara's, are imbedded in popular music. And the playing of Brazilian or international songs, namely Queen, is seen frequently as part of Clara's distinct lifestyle. In order to regain or maintain her spirits, she not only listens constantly to music, be it modern or classical, she also shares this music with those who are close to her. It would take a separate paper to elaborate on this. For now I would like to underline that the often romantic, sometimes sentimental or danceable music by Taiguara, Roberto Carlos, Altemar Dutra, Reginaldo Rossi, Gilberto Gil, Alcione, Maria Bethania e Paulinho da Viola, as well as by Heitor Villas Lobos stimulate an emotional or upbeat reception that might make the spectators connect as much with the characters as with their own memories related to listening to and enjoying music.

As mentioned earlier, the film stirred polemic after its international and national launch. While the international press was favourable, the national press took two opposing

$\mathrm{B}^{\text {RASILIANA-Journal for Brazilian Studies. Vol. 6, n.1 (December, 2017). ISSN 2245-4373. }}$ 
perspectives. For many Brazilian film critics, the character played by Sonia Braga, a television and film star from the 1970s who came to global fame but never got rid of the label as a sex symbol, was simply a spoiled woman with no depth, a lady of leisure who, the owner of another five apartments - as she notes at some point, was unaware of her own class contradictions (Ormanda, 2016; Oliveira, 2016). The whole plot was nothing more than Manichian, a melodrama based on victimization, with no subtlety (Oliveira, 2016; Prado, 2016). Clara's act of revolt was equally dubious because based on the same insidious mechanisms used by the construction company (Ormanda, 2016; Escorel, 2016; Coelho, 2016). Finally, the film was inconclusive and ambiguous (Escorel, 2016), full of contradictions and therefore politically treacherous (Coelho, 2016). The contrary opinion was equally sustained. That Clara was a profound, sensitive and upstanding woman (Fireman, 2016; Romero, 2016; Russo, 2016), that her protest was the result of a necessary political attitude against coronelism and real estate speculation (Russo, 2016; Fireman, 2016). Ultimately, the film displayed the importance of memory in a country blinded by the drive towards progress (Glioche, 2016).

Is Clara a villain or a believable example of the middle class? Does the film inspire resistance against wrongdoings or is it permissive with the country's cordial mentality? Returning to Seel's (2012) definition of film, facing ourselves and the world means in Aquarius to watch a female character of the Brazilian middle class who lives in a privileged environment and is dealing with a situation in which the power structure, in the form of real estate speculation, tries to push her out of her cosy home. Through her we face savage capitalism, presented, however, as a prolongation of the semi-feudal colonial patriarchal economy. Its survival in modern times has not only been described by the already cited Sergio Buarque and Gilberto Freyre, Caio Prado Júnior's analysis of The colonial background of modern Brazil is also worth remembering, since it highlights that the country never developed any other ordering principle capable to substitute colonialism's oppression of vast parts of society: "In short, slavery and the relations that derive from it, although they formed the basis of the only organized sector of colonial society, and thus allowed it to continue and develop, do not, however, go beyond a much lower plane, and did not develop into a larger and more complex superstructure. They served only to momentarily conserve the colony's social nexus." (Prado Júnio, 1967, p. 252).

The difficult place of the middle class within the contemporary neo-colonial sociopolitical structure depicted in Aquarius becomes clearer when one realizes that, historically, there has never been an alternative between participating in imposition or subordination.

$\mathrm{B}^{\text {RASILIANA-Journal for Brazilian Studies. Vol. 6, n.1 (December, 2017). ISSN 2245-4373. }}$ 
This is Clara's challenge when she decides that she does not want to be ordered around in a society that expects from her to be submissive to the ruling class. But in its imaginary world, the film plays with the possibility that the middle class can confront this power structure. This possibility can resonate with our inner life, since we all have experienced situations of pressure and coercion, and our outer reality, since gentrification is an occurrence shared globally. By limiting the perception of our world to this small cosmos, the film enhances what is at stake for the middle class in Brazil and elsewhere: to be aware of and defend a life style, a distribution of the sensible, that is based on civic rights, resumed in the simple desire to remain living where one wants.

When compared to the reaction to the military coup and the impossibility of taking action in Land in Anguish, if we accept the soft coup theses with regard to the impeachment process, Aquarius opens a rather new prospect in Brazilian film narratives. Factually, and the debate on the soft coup reaffirms this, the middle class has always been a strong ally of the upper class, making social and political changes impossible. And not only the middle class but also left-wing politicians. Another commentator of Brazil's historical political difficulties, Roberto Schwarz (2014), argues, that the desire of class conciliation by the left has been responsible for the absence of a class struggle, leading, in fact, to the hard coup in 1964. As I will discuss in due course, this problem was focused for the first time in Cinema Novo's films, especially in Land in Anguish.

\section{Land in Anguish}

Let me now compare Aquarius's 65-year retired rebel, who smokes pot and hires a call boy when an orgy is organized above her head, to a key figure within Brazil's film history, Glauber Rocha's protagonist Paulo Martins, in order to comprehend why her action against the upper class can be considered a role model for middle class spectators. Land in Anguish is part of a group of films that were made right after the military coup in 1964, associated to Cinema Novo. The film critic and scholar Jean-Claude Bernadet (2007, p. 103-4) observes that these films ${ }^{4}$ introduced the urban middle class as main character, displaying it as apathetic, stagnated, distressed and welcoming fascism with open arms. Paulo is a perfect example, even though his condition as poet and journalist should make him less vulnerable

\footnotetext{
${ }^{4}$ Bernadet mentions O Desafio/The Dare (Paulo César Saraceni, 1965), São Paulo S.A. (Luiz Sergio Person, 1965) as the first examples.
}

$3^{\text {RASILIANA- Journal for Brazilian Studies. Vol. 6, n.1 (December, 2017). ISSN 2245-4373. }}$ 
and more capable of resisting the seductive powers of the upper class and their political games. Yet, in Land in Anguish facing the world and ourselves means to recognize that we are incapable of acting since we are imprisoned in our class paradoxes.

Let me recall the storyline: filmed in 1967 the film begins with a coup against the leftwing populist governor Felipe Vieira, a presidential candidate, in the imaginary country Eldorado. It is ultraconservative Porfírio Diaz's answer to his former protégée Paulo's political treason. Faced with the coup, Paulo calls to arms, but Vieira wants to avoid bloodshed. In a suicidal act Paulo is shot by the police and a long flashback narrates his political involvement, first with Diaz and then with Vieira, who are presented as two sides of the same coin. Paulo developed friendships with both men by trying to manipulate them as much as they used and manipulated him. Robert Stam (1995, p. 153) therefore compared the character to Hamlet, calling him a more or less lucid critic of the corruption in which he himself participates. His intent to harmonize politics, ethics and aesthetics fails, since, as Bernadet (2011, p. 155) puts it, politics lack as much ethics as aesthetics. Remembering Rancière, we can question this affirmation. Thus Paulo's incapability to withstand the pressure he himself creates and that literally implodes him should not be tied to outer circumstances, but seen as his particular way, representative of the middle class, in dealing with the situation. His interest is not to bring about change, since he was never guided by an interest in a redistribution of the sensible, although he talks about it. But when it comes down to action, he is only capable of making alliances.

Ismail Xavier (1993, p. 57) interprets it as a revelatory allegory on Brazil $1^{5}$, fuelled by the desire to offer a general diagnostic of the nation, namely of the prolongation of colonialism in the authoritarianism towards the lower classes, a mechanism in which the middle class and Paulo Martins participate (Xavier, 1993, p. 63). But the author emphasizes the film's critique and revelation of the political power plays, especially populism (Xavier, 1993, p. 65), as though this revelation could lead to change. Robert Stam (1995, p. 149-150) reads the film in a similar sense, as an essay on the intersection of art and politics that reveals the subterranean affinities of Paulo with his enemies, while its aesthetics are designed to make the spectator conscious of this. Jean-Clause Bernadet (2011, p. 156) is more sceptical and does not even consider Land in Anguish a political film. The author insists on the film's

\footnotetext{
${ }^{5}$ Glauber Rocha (118) himself describes the film as a parable of left-wing politics in Latin America: "It is, in fact, a parable on the politics of communist parties in Latin America. For me, Paulo Martins represents, basically, a typical Latinamerican communist. He belongs to the party without belonging to it." (my translation)
}

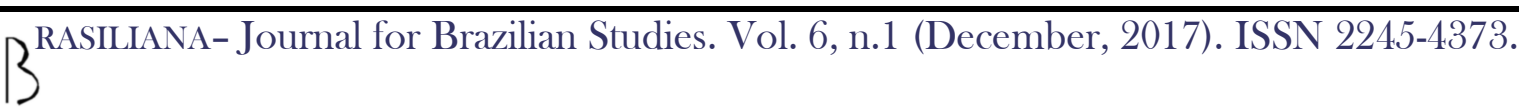


limited scope by arguing that it does not take the political phenomenon in its complexity into regard but only looks at the leadership of the elite, and, more precisely, at what one single person, the protagonist, conceives of as politics. He is also less interested in the film's aesthetics and their revelatory dimension.

The world constructed in the film is strongly in tune with the world after the hard coup, but does not in any moment indicate the possibility of change, not even before the military putsch. Thus, the imaginary world that shows a continent, Latin America, entranced by its very own ambiguities, makes us, more than anything else, experience anguish. In contrast to Aquarius, where the fear - even though against the lower classes - is questioned, we remain in an anxious sate, albeit the possibility of being moved, in the sense that we could comprehend the perverse mechanisms of lobbying, intrigue, abuse and manipulation.

What is more, Land in Anguish neither conceives the people as part of the political system nor the middle class or the intellectuals as agents of transformation. In contrast to Clara's resistance, Paulo's conduct has little or nothing of a role model. His response is always aggressive: at first, against the people, then against the key political figures and finally self-destructive. Even his last gesture of revolt, in which he raises a machine gun, does not imply any constructive political solution.

By simulating a coup in Eldorado, the film is clearly a reflection of the continent's historical process and the biographical experience of the filmmaker Glauber Rocha as an intellectual. These experiences are shaped with sounds and images into a multifaceted aesthetics that makes us feel this bewildering condition, mediating a possible knowledge of the violent constraints of the political situation. In other words, by limiting the perception of our world on the military coup and its preliminaries, the film enhances the sense of frustration and lack of perspective that it implied. The famous ending in which we gaze for long 70 seconds on the intellectual with a machine gun, a phallocentric symbol - strongly linked to Paulo's constant affirmation of his masculinity within a patriarchal and misogynistic society in which he willingly partakes (and the film is not at all critical of this) - , might be considered the very image of the violence that impregnates the continent since its so-called discovery and which still keeps the spectator transfixed. ${ }^{6}$

\footnotetext{
${ }^{6}$ Glauber Rocha (119) comments the film's ending in a very ambiguous way: "It is not a song in socialist realist style, it is not the feeling of the revolution, it is something harder and more serious." (my translation)
}

$3^{\text {RASILIANA- Journal for Brazilian Studies. Vol. 6, n.1 (December, 2017). ISSN 2245-4373. }}$ 


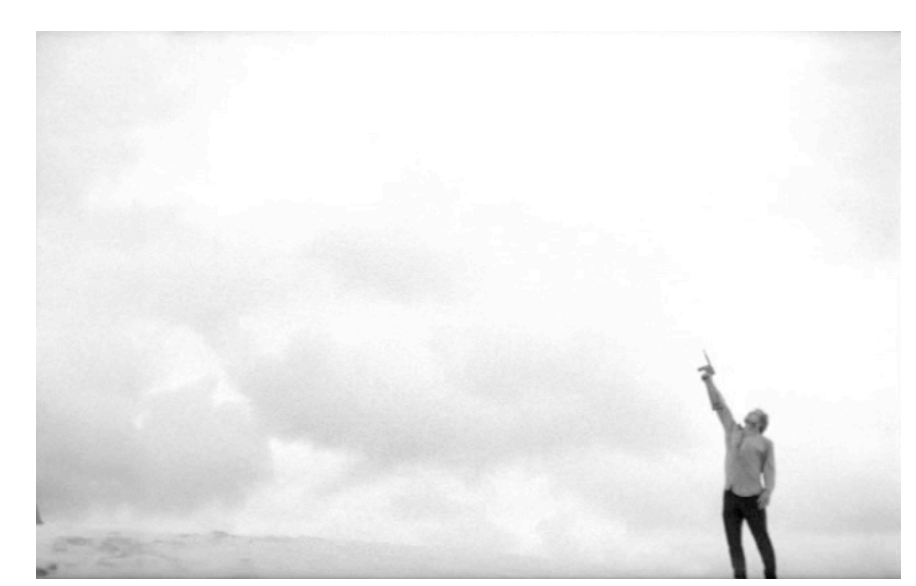

Figura 5: Final shot of Paulo in Land in Anguish (@ Mapa Filmes)

Land in Anguish can make us perceive how we stand towards ourselves: spellbound, incapable of acting beyond the empty gesture of revolt. But understanding the political mechanisms of the elite does neither immediately suggest how we could define ourselves differently, nor how we could re-act. Put differently, there is neither a glimpse of hope nor a horizon of redistributing the sensible. The film might make us move to understand the state in which we encounter ourselves but it offers no idea what so ever of where the people should be, how one could react to leave the paralysing trance.

When we compare Aquarius with Land in Anguish, we can come to a couple of conclusions with regard to the films' potentials to move us and to make us move, in the sense that they can make us feel and understand Brazil, and make us act within its sociopolitical structure. As I said in the beginning, Land in Anguish was filmed as a direct reaction to the military coup of 1964 and features an intellectual who is nothing more than a betraying and betrayed mediator, albeit his final desire to radically negate the system, as Bernadet (2009, p. 158) advocates. Incapable of separating the personal from the political, we see him oscillating and struggling between dedicating himself to his poetry or trying to participate in politics by partaking in its intrigues. It is the only action he is capable of within the circumstances he finds himself in and that correspond historically to the oppression of a military dictatorship. His political projects are never more than discourses.

Aquarius, on the other hand, was launched briefly after what has been considered a blow to the young Brazilian democracy - whose first free elections occurred in 1986 - and was used as a platform for protest. In contrast to Land in Anguish, it was filmed in a climate of public demonstrations, politically inspired actions, which began in 2013 as popular protest, initiated by students against raised bus fares, and then turned into an outcry against

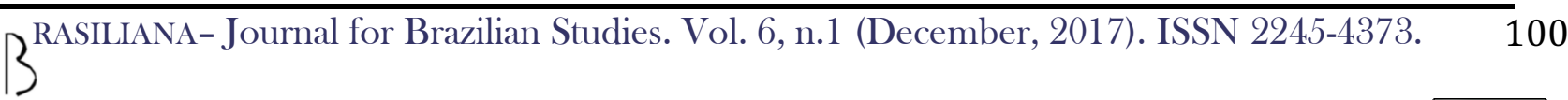


corruption. When Rousseff was re-elected at the end of 2014 and her government entered economical and political turmoil, the demonstrations turned against her, being now led mainly by the middle and the upper classes in favour of the impeachment. This bonding might have been a clear sign to conservative politicians that a legally questionable impeachment process would not be contested but rather supported. As Darcy Ribeiro (2000) notes, the common mechanism of the Brazilian ruling class are preventive revolutions that arise from the fear of the lower classes and lead to dictatorships: "The great challenge that Brazil faces is to achieve the necessary lucidity to connect these energies [the social antagonisms] and guide them politically, with a clear awareness of the risks of setbacks and the possibilities of liberation they bring."

While the success of the impeachment process - interpreted as a soft coup - might be read as repeating the alliance between the middle and the upper class, Aquarius suggests a different way of defining ourselves, i.e. the Brazilian middle class. I would suggest that this definition is closer to the initial impulse of the protests, which occurred without any defined leadership. The main character, Clara, is also an intellectual - a music critic - yet, in contrast to Paulo Martins, neither an artist nor involved in politics. Notwithstanding, her attitude to defend her personal rights is clearly connected to the historically rooted coronelism and to global capitalism. Interestingly, in a moment of crisis, the middle class is again seen as an anchor of values as it used to be in bourgeois drama and melodrama. Even though a victim of the upper class, since Clara will not be able to live in her home anymore, the very fact that she resists is presented as a virtue and makes the film stand out among contemporary and historical audio-visual productions.

The star persona Sonia Braga is extremely important in this clever strategy of the filmmaker to move us and - following her example - make the middle class audience believe that it could not only move - understand what is going on - but also act as citizens and against social injustice - even though this is reduced to the defence of personal property and constrained to being a revolt against cordiality. A respected national and international star and former sex symbol, Sonia Braga as Clara shows us as much a vulnerable elderly woman - widowed, tired and marked by life through a huge scar that took the place of one of her breasts - as well as someone who has various strategies to confront life - dancing, smoking pot, drinking and having sex. Less poetic, less intellectual, less confused and not kept in trance by a dictatorship, as Paulo in Land in Anguish, in 2016 we encounter this modern Amazon willing to fight individual and social cancer, suggesting that we should act when we are coerced. Kleber Mendonça Filho restricts himself with Clara to trying to preserve the

$\beta^{\text {RASILIANA- Journal for Brazilian Studies. Vol. 6, n.1 (December, 2017). ISSN 2245-4373. }}$ 101 
current distribution of the sensible, while her masculine counterpart remains paralyzed in his phallocentric world for which Glauber Rocha is incapable of pointing out an alternative, neither of recovering the former distribution nor to establish another. Both film's share the diagnostic that the ruling class will always make preventive coups in order to remain their privileges and that the middle class equally struggles to give up theirs. Curiously and consequently, the film crew followed Clara's lead and took sides against the debatable incrimination of Brazil's last democratically elected president, which is bringing us nearer to the conservative and restrictive distribution of the sensible at the times of the hard coup. Whereas Land in Anguish could not even imagine the middle class to act, Aquarius tries to move it in this direction. Interestingly, Paulo's trance becomes Clara's nightmare, but while Paulo is incapable of freeing himself and ends up in self-destruction, Clara wakes up and decides to emancipate herself, even though her success is - for now - limited.

\section{References}

Araujo, Inácio. "Sonia Braga espetacular em filme construido meticulosamente." Folha de São Paulo. www1.folha.uol.com.br, 30 Aug. 2016. Web. 26 Sept. 2016.

Balee, Wiliam. "The Brazilian People: The Formation and Meaning of Brazil." Tipití: Journal of the Society for the Anthropology of Lowland South America, 1.2 (2003): 232-37.

Bernadet, Jean-Claude. Cinema brasileiro. Propostas para uma história. São Paulo: Companhia das Letras, 2009.

Bernadet, Jean-Claude. Trajetória crítica. São Paulo: Martins Fontes, 2011.

Bernadet, Jean-Claude. Brasil em tempo de cinema. Ensaio sobre o cinema brasileiro de 1958 a 1966. São Paulo: Companhia das Letras, 2007 [1967].

Celarent, Barbara. “The Masters and the Slaves by Gilberto Freyre." American Journal of Sociology, 116.1 (2010): 334-39.

Coelho, Marcelo. "Aquarius oferece versão de esquerda para tradição família e propriedade." Folha de São Paulo. wwww1.folha.uol.com.br, 18 Sept. 2016. Web. 26 Sept. 2016.

Escorel, Eduardo. “Aquarius - o filme em questão. Piaui. www.piaui.folha.uol.com.br, 8 Sept. Web. 26 Sept. 2016.

$\mathrm{B}^{\text {RASILIANA-Journal for Brazilian Studies. Vol. 6, n.1 (December, 2017). ISSN 2245-4373. }}$ 102 
Fireman, Chico. "Arte e política andam juntas em 'Aquarius' mas polêmica não se justifica." UOL. www.cinema.uol.com.br, 29 Aug. 2016. Web. 26 Sept. 2016.

Freyre, Gilberto. The Masters and the Slaves. New York: Knopf, 1946 [1933]. Translation. Glioche, Reinaldo. "Intenso e sensorial, 'Aquarius' é muito mais do que metáfora política." Gente. www.gente.ig.com.br, 1 Sept. 2016. Web. 26 Sept. 2016.

Johnson, Randal; Stam, Robert. Brazilian Cinema. New York: Columbia University, 1995 [1982].

Holanda, Sergio Buarque. Roots of Brazil. Notre Dame: University of Notre Dame Press, 2012 [1947]. Translation.

Menonça Filho, Kleber, director. Aquarius. Vitrine Filmes, 2016.

Moraes, Camila. "Censura e protestos aumentam expectative sobre filme 'Aquarius'." El País Brasil. www.elpaisbrasil.com, 2 Set. 2016. Web. 26 Set. 2016.

Oliveira, Rodrigo Cassio. "Aquarius (Kleber Mendonça Filho, 2016)." www.rodrigocassio.com, 11 Sept. 2016. Web. 26 Sept. 2016

Ormanda, Andrea. “O país do cinismo.” Cinética. www.revistacinetica.com.br, 19 Sep. 2016. Web. 26 Sep. 2016.

Prado, Carol. "Aquarius faz reflexão ponderosa mas tem vilão simplista." O Globo. www.g1.globo.com, 1 Sept. 2016. Web. 26 Sept 2016.

Prado Júnior, Caio. The colonial background of modern Brazil. Berkeley: University of California Press, 1967 [1942]. Translation.

Rancière, Jacques. “Thinking of Dissensus: Politics and Aesthetics.” In: Reading Rancière, edited by Paulo Bowman and Richard Stamp. London/New York: Continuum, 2011: 1-17.

Ribeiro, Darcy. The Brazilian People: The Formation and Meaning of Brazil. Miami: University Press of Florida, 2000 [1993]. Translation.

Rocha, Glauber Rocha, director. Terra em Transe/Land in Anguish. Mapa Filmes, 1967.

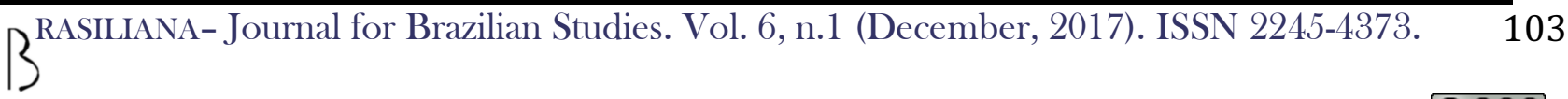


Rocha, Glauber. Revolução do Cinema Novo. São Paulo: CosacNaify, 2005.

Romero, Simon. "Brazilian Politics smother a film's Oscar ambitions." The New York Times. www.nytimes.com, 28 Sept. 2016. Web. 1 Oct. 2016.

Romero, Heitor. "O que o tempo não leva." Cineplayers. www.cineplayers.com, 5 Sept. 2016. Web. 10 Sept. 2016.

Russo, Francisco. “O valor da memória.” www.adorocinema.com. Web. 10 Sept. 2016.

Schwarz, Roberto. As ideias fora do lugar. São Paulo: Penguin \& Companhia das Letras, 2014.

Seel, Martin. Die Künste des Kinos. Frankfurt a.M.: S. Fischer, 2013.

Xavier, Ismail. Alegorias do subdesenvolvimento. Cinema Novo, Tropicalismo, Cinema Marginal. São Paulo: Editora Brasiliense, 1993. 